\title{
The Economic Returns of Network Resources to the Urban Informal Economy: Evidence from Street Vendors in Addis Ababa, Ethiopia ${ }^{1}$
}

\author{
Getahun Fenta Kebede and Francesca Odella ${ }^{\mathrm{b}}$
}

\begin{abstract}
It is widely recognized that social capital constitutes an important form of social regulation in informal sector and it is the major component of the asset portfolios of the urban poor. Nevertheless, the potential contribution of social capital in the informal sector remains under-investigated in African cities. Applying the network approach, this study examined the economic returns of social capital to microenterprises in the informal sector. To do so, the personal networks of street vendors in Addis Ababa were examined. Multi-stage sampling procedures involving purposive and systematic random-walk techniques were applied to draw samples. Data were collected through position generator surveys. The data were analyzed using OLS and Instrumental Variable Estimators. By controlling the potential endogeneity, the estimation results revealed that network resources are positive and significant predictors of enterprise profit. But their benefit is less for married vendors than unmarried ones. The human capital measures such as education, vocational training, and business experience are not significant predictors of enterprise profit.
\end{abstract}

Key Words: Social Capital, Social Networks, Informal Sector, Ethiopia, Addis Ababa

\section{Introduction}

The role of social capital (SC) in economic development has got increased attention since the 1970s (Portes, 1998a; Woolcook, 2001). Views vary on what constitutes SC, how it operates, and how it is defined and measured. Bourdieu (1986, 284) defines SC as 'the aggregate of the actual or potential resources which are linked to possession of a durable network of more or less institutionalized relationships of mutual acquaintances and recognition'. Coleman (1988) defines SC as resources embedded in networks that allow individuals and communities to achieve their desired goals. Putnam $(1993,167)$ treats SC as 'the features of social organization such as trust, norms, and networks that improve the efficiency of society by facilitating coordinated actions'. While Portes $(1998,8)$ defines SC as 'the ability to secure benefits through membership in networks and social structures', Lin $(1999,35)$ describes it 'as resources embedded in social structures which are accessed and/or mobilized in purposive actions'.

Despite several attempts to define SC, its definition has remained elusive (Durlauf and Fafchamps, 2004). Lack of a clear definition has led to measurement problems of SC. Review of the literature has, however, shown that there are two perspectives upon which empirical studies have been conducted. The first focuses on behavioural variables: trust, norms, and values. The second approach involves measuring the position of individuals 
in networks (Adam and Rončević, 2003). This study has applied the social network (SN) approach because SC exists in the $\mathrm{SNs}$ and $\mathrm{SNs}$ facilitate expectations and trustworthiness among the actors in the network (Coleman, 1988). SC is rooted in SNs and must be measured relative to its roots'( Lin, 1999). The network dimension of SC also focuses on individuals and their ability to secure benefits by virtue of positions in a network (Portes, 1998a).

An examination of entrepreneurship literature has shown that $\mathrm{SNs}$ help entrepreneurs to obtain information, advice, and support from alters (Aldrich and Zimmer, 1986; Birley, 1985), control and manage exchange structures (Larson, 1992), and get financial capital (Uzzi, 1999). SNs also help entrepreneurs to manage crisis (Lourencco-Lindell, 2002), access and share market information (Fafchamps and Minten, 1999, 2001), facilitate firm innovation (Singh et al. 1999; Cantner, Conti, and Meder, 2009), for greater acquisition of firm capabilities (Zaheer and McEvily, 1999), and for financial performance and innovative capability of firms (Baum, Calabrese, and Silverman, 2000). In contrast, there are evidences that show SC have negative effects in that tightly controlled relationships reinforce social obligations that limit the freedom of economic agents to discover and utilize new opportunities(Uzzi, 1997; Light and Isralowitz, 1997; Podolny and Page, 1998). These relationships might be social problems that confine entrepreneurs to rentseeking activities (Gambetta, 1996; Portes, 1998b; Meagher, 2005).

Despite the rhetoric and growing research on SNs, there are ongoing debates about the significance of SNs (Brüderl and Preisendörfer, 1998;Baum et al., 2000). This is mainly because researchers have used different definitions of the concept, levels of analysis, and research approaches (Berrou and Combarnous, 2012). Some researchers use qualitative techniques, others applied quantitative approaches, and yet others employed mixed methods (Edwards, 2010). Indeed, most studies have been conducted in advanced economies with large-scale enterprises and formal employment conditions with less attention to LDCs where SC plays a vital role in informal activities (Thrikawala, n.d.). The existing SN studies in Africa focus on rural households (Durlauf and Fafchamps, 2004) with limited attention to urban areas where the majority of the urban poor are engaged in the informal sector (Rutashobya, Allan, and Nilsson, 2009).

Applying quantitative methods, this study investigates the causal effect of SNs on the performance of microenterprises in the informal economy ${ }^{1}$. The informal economy is the main source of employment and livelihood for the urban poor (Becker and Sida, 2004). But as operators of the informal economy work outside government regulations, they have less access to financial and physical resources and are excluded from government institutions (Chen et al., 2005). Instead, they depend on social capital schemes to solve their material and non-material problems (Berrou and Comamous, 2012). To ascertain the importance of SC to economic efficiency in Africa, therefore, the focus should be on the informal economy as it highly depends on SC mechanisms compared with formal and large-scale enterprises (Hynes, n.d). By examining the role of network resources on enterprise profit, this study will contribute to the literature on the implication of SC for the informal economy. Testing the social resources theory into the Ethiopian context,

${ }^{1}$ ILO defines the informal sector as activities comprising unregistered microenterprises that operate at low levels of organization and on a micro-scale. It is an urban livelihood strategy characterized by low entry barriers in terms of skill and capital; family ownership of enterprises; labor-intensive production; no access to formal credit, low skills; low levels of education and training; low incomes; and unregulated markets (ILO, 1972). 
the study will also contribute to broaden the relevance of the theory to the circumstances of LDCs where SC is an integral part of people's day-to-day survival.

\section{Theoretical Framework and Literature Review}

In the informal economy context, individuals' $\mathrm{SN}$ structure is a key determinant of enterprise performance (Uzzi, 1999). Although Granovetter's (1973) weak ties theory and Burt's (1992) structural holes theory have been widely applied in the entrepreneurship studies, this study uses Lin's (1982) social resource theory. Lin's (1982) social resource theory focuses on resources embedded in networks. Taking a hierarchical view of social structure, Lin argues that access and use of social resources can lead to better economic outcomes. The concept social resource has two components: social relations and the resources embedded in relations. While personal resources refer to individual's wealth, status, and power; social resources are embedded in the positions of alters that an ego obtains through his/her network (Lin, 1999). Social resources are, thus, not possessed by individuals rather they belong to members of a network (Lai, Lin, and Leung, 1998).

The premises of the social resources theory is that egos with access to better social resources will obtain better outcomes (Lin, 1982). In job-search, for example, social resources provide access to information about attractive jobs (Lai et al., 1998). The theory claims that the success of an action depends on the presence of high social position contact in a network and the status diversity of a network (Berrou and Combarnous, 2011). Valued resources in a society are represented by wealth, power, and status. It argues that occupational prestige is a good indicator of social resources and alters with higher prestige possess more resources and have more influence on economic outcomes of egos (Lin, 1982). Yet there is a question as to how resources are measured. Lin (1999) has made a distinction between contact resources and network resources. While network resources refer to resources embedded in ones networks, contact resources refer to contacts used as assistants in instrumental actions. Network resources represent accessible resources and contact resources refer to resources mobilized for instrumental actions ( Lin, 1999).

Most of the previous studies, for instance, Lin, Ensel, and Vaughn (1981), Marsden and Hurlbert (1988), De Graaf and Flap (1988), Sun and Hsung (1988), and Berrou and Combarnous (2012) have focused on the contact resources perspective. The findings of these studies show that higher occupational position of alters is associated with better outcomes. Likewise, Son and Lin (2012) found that the diversity of contact resources gives a relative advantage for instrumental actions. Kalmijn and Flap (2001) also found out that contact network diversity reduces the degree of in-group constraints on resources. Personal networks that are composed of resource-rich and powerful contacts generate higher rates of return when they are mobilized (Batjargal, 2003). Moreover, Uzzi, (1996) found that heterogeneity in contact resources of entrepreneurs influences the performance of enterprise.

Some other studies, (e.g. Lin and Dumin, 1986; Van der Gaag, Snijders, and Flap, 2004; Van der Gaag, 2005) focus on network resources measured by the range of occupational status, network range, and the highest occupational status reached. The findings of these studies show that access to alters having higher socioeconomic status leads to better outcomes. In sum, studies on contact and network resources have revealed that both the 
availability and the actual mobilization of resources play a crucial role in finding jobs (Lai et al., 1998). This study tests if network resources influence microenterprise performance. We focus on measuring SC within the 'access' perspective, and define SC as the collection of all potentially available alter resources (Van der Gaag a Snijders, 2005). We hypothesize that the larger the SC volume, the better the enterprise performance.

\section{Research Methods}

\subsection{Study Site and Sample Design}

This study is conducted in Addis Ababa. Addis Ababa is the capital and the primate city of Ethiopia. With a population of 3 million, Addis Ababa accounts for 25 percent of the entire urban population of the country (CSA, 2008). It is a seat for many international organizations including the African Union and the Economic Commission for Africa and is the hub of social and economic infrastructure in the country. With rapid natural population growth and high rate of rural-urban migration (accounting for about 40 percent of its growth) Addis Ababa is one of the fastest growing cites in Africa. This has created unemployment problems in the city and hence migrants are forced to join street vending (UN-Habitat, 2008).

To obtain network data we follow an ego-centred network approach ${ }^{2}$. Data were collected from street vendors. Standard sampling and estimation techniques require drawing samples with a known probability of selection. This means that a researcher must have a sampling frame to select samples. Unfortunately, street vendors in Addis Ababa are not recorded in the government statistics. This has created a problem when it comes to getting sampling frame for the study. Such special populations are called "hidden" (Salganik and Heckathorn, 2004) or "hard-to-reach" populations (Muhib et al., 2001). In cases where no list exists from which a random sample can be drawn using conventional sampling techniques, a combination of "time-space" (Muhib et al., 2001) and "random-walk"( Singh, 2007) sampling procedures can be used alternatively.

Multi-stage sampling procedures were applied to draw samples. We consulted informants in the city to gather information for sampling. Based on our consultation, a two days tour was organized in the ten sub-cities of Addis Ababa to identify street vending cluster sites. Following our tour, ten street vending cluster sites (one from each sub-city) were identified purposively. Once cluster sites were identified, we observed the date and time when vendors get concentrated in these areas. We found street vendors working in all days of a week and from $5 \mathrm{pm}-8 \mathrm{pm}$ is the time for immense gathering of street vendors. This is the time when people get out of work and thus vendors use this particular time to sell their products to their customers. These specific place and time arrangements form the primary sampling units and were used to construct the sampling frame. Since the space-time arrangements are sampled with a known probability, it is possible to make statistical inference about the population under study (Muhib et al., 2001).

Once the space-time preparation is set, samples were drawn using systematic randomwalk techniques. We followed specific random procedures depending on the nature of the cluster site. The procedure involves taking the first road right or left of the sample

2 An 'ego-centred' or 'personal network' is defined as an actor's set of relations with other actors. It is composed of a focal actor ('ego'), ego's direct contacts ('alters'), and the ties between them. The ego-centre perspective conceptualizes networks to decouple the social context in which individuals are embedded and is based on 'methodological individualism' .Its objective is to examine local network structure (Odella 2006:1; Carrasco et al. 2008). 
site and then interviewing every $2^{\text {nd }}, 5^{\text {th }}, 7^{\text {th }}$, or $10^{\text {th }}$ vendor or interviewing every street vendor after a 2, 5, 7 or 10 feet walk right or left of the road. The application of this procedure and the number of samples drawn has varied from one cluster site to another depending on the pattern, size, and density of vendors in each location. Since the total population was unknown a priori, a proportionate size was fixed to draw samples in each selected site. The sample size was determined based on the volume of vendors in each location. Considering the extensive nature of the questionnaire and the challenge of collecting SN data, a total of 154 street vendors were drawn from the ten cluster sites.

Table1: Distribution of samples with their respective sub-cities and cluster sites

\begin{tabular}{|l|l|l|l|}
\hline Sub-city & Cluster site & Freq. & Percent \\
\hline Addis Ketema & Mercato & 23 & 14.94 \\
\hline Akaki-Kality & Kality Gebriel & 11 & 7.14 \\
\hline Arada & Piassa & 23 & 14.94 \\
\hline Bole & Gerji & 10 & 6.49 \\
\hline Gulele & Addisu Gebaya & 14 & 9.09 \\
\hline Kirkos & Kazanchis & 13 & 8.44 \\
\hline Kolfe-Keranio & Ayer Tena & 11 & 7.14 \\
\hline Lideta & Mexico & 16 & 10.39 \\
\hline Nefas silk-lafto & Saris & 10 & 6.49 \\
\hline Yeka & Megenagna & 23 & 14.94 \\
\hline & \multicolumn{1}{|c|}{ Total } & 154 & 100.00 \\
\hline
\end{tabular}

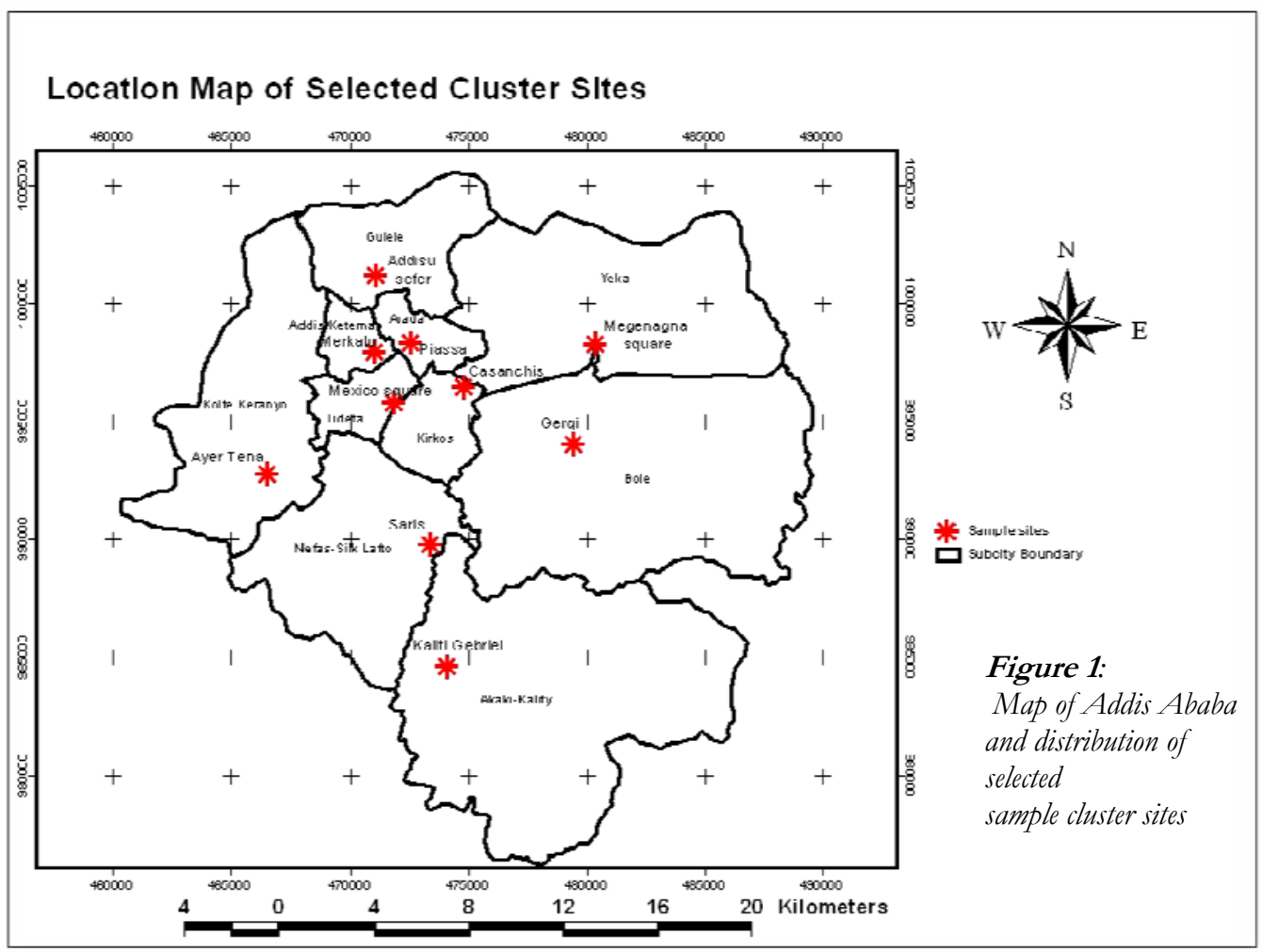




\subsection{Data and Data Collection Tools}

Data were collected using questionnaire. The questionnaire consists of street vendors' dataset and network dataset. Network data were collected using the position generator instrument developed by Lin and Dumin (1986). In this method, respondents are asked whether they knew a person in certain occupation, and if yes, whether a person named is a relative, a friend or an acquaintance. The acquaintance-friend-family ties represent an increasing order of tie strength (Van der Gaag, 2005). The assumption is that the stronger the tie, the greater the compliance of alters to give access to resources to an ego. The position generator consists of the three dimensions of SC- the presence of alters, the resources of alters, and the accessibility of these resources to an ego ( $\mathrm{Lin}, \mathrm{Fu}$, and Hsung, 2001;Van der Gaang, 2005). It focuses on accessibility of potentially available resources but not the actual use (Van der Gaag, Snijders, and Flap, 2004; Van der Gaang, 2005).

In previous studies, (e.g. Van der Gaag, 2005), the construction of position generators is based on occupations sampled from a census listing for a population under study. Review of the literature shows that the number of occupations to be listed has varied between ten (Bian and Ang, 1997) and forty five (Boxman, De Graaf, and Flap, 1991). In the Ethiopian context, there is no organized census result that lists occupations. Due to lack of such data, we identified a list of forty occupations which are common in Ethiopia and respondents were asked to mention if they knew people who hold those occupations. Once data were collected, we used the International Standard SocioEconomic Index $(\text { ISEI })^{3}$ of occupational status to determine occupational prestige. Socioeconomic indices refer to human resources and economic rewards and hence they indicate social resource associated with each occupation. ISEI measures exist for many countries and hence are more commonly used by researchers because they capture the basic parameters of the process of occupational stratification (Ganzeboom and Treiman, 2003).

\subsection{Variables and their Measurement Dependent Variable: Profit}

Enterprise performance is a dependent variable. In the literature there are various indicators of enterprise performance such as growth in sales, business turnover, profit, assets, enterprise survival, and employment growth (Garoma, 2012). Employment growth is one of the most frequently used measures (Bigsten, 2007; Gebreyeesus, 2009). An enterprise is successful if it increases the number of its employees. The assumption is that growth in employment size is related to enterprise profit (McPherson, 1996). In this study, the use of employment growth is not viable because street businesses are usually managed by a single person. McPherson (1995) measures performance by enterprise age. The logic is that the longer the age in business, the more successful the business is. Business survival, however, requires panel data (Garoma, 2012) and hence not applicable in cross-sectional studies. Robb and Fairlie (2007) use profit as an indicator of enterprise success. Van Dijk (2005), however, argues that as business owners do not keep complete record of business transactions, they might not realize the true financial values.

\footnotetext{
${ }^{3}$ For the details see Ganzeboom and Treiman (2003).
} 
Estimating profit is also sensitive to regulation and taxation problems. In addition, personal and business accounts are typically blend within a single cash box (Honig, 1998). Despite such problems, profit is the most widely used measure of enterprise performance.

We used profit as an indicator of enterprise performance. This is because the ultimate objective of enterprise formation for street vendors is earning income to sustain their urban life (Kantor, 2005). To establish reliable profit, street vendors were asked a series of questions related to average monthly business expenses and average monthly sales volume. Profit was, therefore, reduced by expenses including wages, rent, repairs, supplies, parts and maintenance. Income derived from other sources was excluded from profit calculation. Profit is expressed in Ethiopian currency, i.e., Ethiopian Birr (ETB) and its logarithm is used to pull outliers from a skewed distribution closer to the bulk of data to be normally distributed.

\section{Independent Variable: SC Volume}

Researchers have used various indicators to measure network resources. These measures are derived from position generator data (Van der Gaag, 2005). 'Upper reachability', which is defined as the highest prestige accessed is one of the measures. 'Resource heterogeneity' is the second measure and is defined as the range in accessed prestige. It is computed as the difference between the lowest and the highest prestige accessed by a respondent (Lin 1999). The third measure is 'extensity of network positions'. It measures the number of positions accessed in a network (Lin, 1999; Lin, 2002; Van der Gaag, Snijders, and Flap 2004). The SC volume is the fourth measure. It is the sum of the prestige of all accessed occupations (Van der Gaag, 2005). The fifth indicator is average accessed prestige. It is total accessed prestige divided by the number of accessed positions that the respondent knows(Campbell, Marsden, and Hurlbert, 1986).

There are problems in some of these position generator measures. For example, number of accessed positions and range in accessed prestige show variations in SC accessed by respondents. However, the problem is that two individuals can access the same number of occupations or ranges in prestige but while one person mostly accesses high prestige positions, the other might access low prestige occupations (Van der Gaag, 2005). Yet, using average accessed prestige has limitations in that one person having access to one position and another person with access to many positions might have the same mean. Using these measures in the regression model may lead a biased result. In addition, we did regression analysis involving the position generator measures and controlled variables. The results show the presence of multi-collinairity problem between the network measures with an average variance inflation factor of 39.25. Due to such limitations, we used SC volume as a proxy measure of network resources as it gives a valid estimate of total resources accessed by a respondent.

\section{Control Variables: Entrepreneur and Enterprise Characteristics}

We controlled for variables that have been shown to influence enterprise performance. We controlled for age of respondents assuming that it does have inverse relation with profit. As individuals grow older, they are less likely to invest to expand 
their enterprise and hence less income achieved (Rooks, Szirmai, and Sserwanga, 2009). Gender is included in the model to control for various characteristics such as trouble to manage business and household duties, restricted mobility, physical strength, nature of business, and discrimination. Gender is a dummy variable (women $=1$ ). Human capital is positively related to profitability. Aspects of human capital that are pertinent to economic outcomes include vocational training, formal education, and previous business experience (Kantor, 2005).We include education by respondents' years of schooling. Vocational training is a dummy variable capturing if a respondent has training before or after starting business. Age of an enterprise is another factor that is accounted for. The presence of a spouse might have a positive influence on profit. We added a dummy variable marital status (married $=1$ ).

Indigenous ethnicity is included into the analysis as different ethnic groups might have different business behaviour. Ethnicity is dichotomous variable equal to unity if Ambara or Gurage in reference to Oromo. We anticipated that factors of production such as working capital have a positive effect on profit. We also propose that family size will contribute labour for street business and influence performance positively. We added location dummies to control for differences in business environment across space. We also tested interaction variables by adding a term to the model in which two independent variables are multiplied. Accordingly, interaction terms which significantly influence profit were added in the model

\section{Model Specification and Managing Endogeneity}

The equation used to measure the effect of $\mathrm{SC}$ volume on profit is written as: $\log \left(\right.$ Profit $\left._{i}\right)=\beta_{0}+\beta_{1} \mathrm{SCi}_{\mathrm{i}}+\beta_{2} \mathrm{HC}_{\mathrm{i}}+\beta_{3} \mathrm{IC}_{\mathrm{i}}+\beta_{4} \mathrm{EC}_{\mathrm{i}}+\mu_{\mathrm{i}}$

Where,

$\log \left(\right.$ Profit $\left._{\mathrm{i}}\right)=$ the logarithm of profit for a street vendor $\mathrm{i}$

$\mathrm{SC}_{\mathrm{i}}=$ measure of individual i's endowment of SC measured by SC volume

$\mathrm{HC}_{\mathrm{i}}=$ street vendor's endowment of human capital (education in years, business experience, and vocational training)

$\mathrm{IC}_{\mathrm{i}}=\mathrm{a}$ vector of individual characteristics (age in years, gender, working age family size, marital status, and ethnic background)

$\mathrm{EC}_{\mathrm{i}}=$ enterprise characteristics (working capital, age of an enterprise, and location of enterprise)

$\mu_{\mathrm{i}}=$ unobserved disturbances and potential measurement errors.

The above OLS model is based on the assumption that SC is part of the individuals' exogenous asset endowment. But in reality this claim usually does not hold true ( Fafchamps and Minten, 2002). For example, the formation of SC needs investment in time and other resources. Individuals with higher profit can, therefore, invest more resources to network formation and accumulate SC. In this case reverse causality might occur from profit to SC formation. In statistical terms, SC becomes endogenous and its estimated coefficients will be biased if profit is estimated by OLS. It is, therefore, necessary to single out the exogenous effect of SC on profit. The solution is the use of instrumental variables (IVs) ( Baum, 2006; Wooldridge, 2010). 
Previous studies (e.g.Narayan and Pritchett, 1999; Grootaert and Bastelaer, 2002; Glaeser, Laibson, and Sacerdote, 2002) have used trust as an IV of SC. Nevertheless, the use of trust as an IV was criticized by Putnam (2000). Putman (2000) argues that rich individuals may have higher tendency to trust and hence using trust as IV can be misleading. Adepoju and Oni (2012) used length of residency in ones location and membership in a religious body IVs for SC. Berrou and Combarnous (2011) used the number and the proportion of ties created before business start-up as an IVs. Fafchamps and Minten (2002) used individual's socio-demographic characteristics and place of birth.

In this study, we used religion dummy as IV for SC volume. Ethiopia is known for the coexistence of various religious traditions. Most people attend religious services either daily or weekly depending on the respective sect of each religion. Churches, mosques, and other houses of worship provide an institutional base for civic good works and a training ground for entrepreneurs (Hopkins, 2011). Regular religious service attendees meet many people daily or weekly making religious institutions as a prime forum for SC formation (Hopkins, 2011). Religion through worshiping places and membership in spiritual institutions, offers an opportunity to access social resources (Miguel, 2004). We also believe that Ethiopia's stock of SC formation is mostly religiously affiliated.

To circumvent the endogeneity effect of SC, three IV estimators: two-stage least squares (2SLS), limited-information maximum likelihood (LIML), and the generalized method of moments (GMM) were estimated using STATA. After running these estimators, we did test of endogeneity to see if SC volume supposed to be endogenous in the first OLS model might be treated as exogenous or not. While the 2SLS estimation provides the Durbin and Hausman statistics, the GMM estimation reports the $\mathrm{C}$ statistic. In both cases, if the test statistic is significant, SC volume must be treated as endogenous. The estimated Durbin, Hausman, and C statistics were found to be $1.54(0.21)^{4}, 1.38(0.24)$, and $1.47(0.23)$ respectively. These endogeneity test results are not significant. Therefore, we have to accept the exogeneity of SC volume. Indeed, religion can be an instrument for the regressor SC volume if it is (a) uncorrelated with the error term $\mu$; and (b) correlated with SC volume (Wooldridge, 2010). To examine the validity of religion as an IV, we did tests of the strength of instruments. For each IV estimator, F tests are reported. While the 2sls and LIML models have the F test result of 6.85(0.00) each, the GMM estimator have got the robust F statics of $8(0.000)$. The estimated F statistics are significant under the three estimators. This indicates that religion dummy is a valid IV for SC volume.. We are now able to assess the exogenous effect of SC volume on enterprise profit.

\section{Results and Discussion}

\subsection{Distribution of Position Generator Items}

Given the 40 occupations, to the average, 33 percent of the respondents stated they knew at least one alter in any of the three types of relationships. The average number of positions accessed by respondents was 13 . The occupations which get greater than 50 percent responses in descending order are petty traders, farmers, business persons, drivers, teachers, daily labourers, police, waiters, brokers, security, and cleaners. These

\footnotetext{
${ }^{4}$ Figures in parentheses are p-values
} 
are low prestige occupations. In contrast, occupations with high prestige scale have got low responses. These occupations include engineers, accountants, bank mangers, university professors, information technologist, artists, company director, policy advisors, and higher level civil servants. All these occupations have got a response of less than 10 percent. This implies that the poor do have less access to high prestige occupations; instead, they do have access to lower prestige occupations. On average, 26 percent of the occupations are accessed through family members, 27percent through friends, and 54 percent through acquaintances. Acquaintances are the source of access for almost all occupations. In other words, on average acquaintances gave access to more different occupations than family and friendship relationships. According to the social resource theory, this means that the weaker the tie, i.e., acquaintance, the lesser the probability that alters can give access to resources to an ego.

\subsection{Characteristics of Respondents}

Men and women are equally represented in the sample. Ethnic wise, the Gurages account for about 36 percent of the samples followed by Ambaras 35 percent and the Oromos 29 percent. Street vendors are young (29.9 years on average) and, on average, their working age family size is 2.74 . Most of the respondents are either illiterate or they have attended only primary and some secondary education. Regarding religion, 69 percent are followers of Orthodox Christianity, followed by Muslims, 21 percent, and Protestants, 10 percent. About 32 percent of the respondents are married. The average age of respondents is 30 years. Table 2 below shows description of the variables used in the regression model.

Table 2: Descriptive statistics of variables used in the regression model

\begin{tabular}{|l|l|l|l|l|}
\hline Variable & Mean & Std.Dev & Min & Max \\
\hline Gender & 0.5000 & 0.5016 & 0 & 1 \\
\hline Marital status & 0.3181 & 0.4672 & 0 & 1 \\
\hline Location dummy & 0.4480 & 0.4989 & 0 & 1 \\
\hline Age of respondents & 29.94 & 8.15 & 15 & 60 \\
\hline Working age family size & 2.74 & 1.98 & 0 & 11 \\
\hline Working capital & 1120.95 & 1398.67 & 150 & 6000 \\
\hline Profit & 764.21 & 365.51 & 200 & 1500 \\
\hline Previous business experience & 0.5741 & 0.4964 & 0 & 1 \\
\hline Vocational training & 0.1948 & 0.3973 & 0 & 1 \\
\hline Age of business & 6.90 & 4.93 & 3 & 28 \\
\hline Social capital volume & 527.07 & 250.68 & 75 & 1369 \\
\hline Years of education & 4.94 & 4.21 & 0 & 16 \\
\hline Ethnic Gurage & 0.3636 & 0.4826 & 0 & 1 \\
\hline Ethnic Amhara & 0.3506 & 0.4787 & 0 & 1 \\
\hline Gender*marital status & 0.2077 & 0.4070 & 0 & 1 \\
\hline Marital status*SC volume & 167.97 & 287.68 & 0 & 1199 \\
\hline
\end{tabular}

The data on migration status shows that 93 percent of the respondents are migrants. This supports the argument that the informal sector is the source of employment and the last option for urban immigrants. About 76 percent of the respondents joined street vending due to lack of employment opportunities. The rest 24 percent enter into street vending voluntarily to supplement income from other sources. For 97 percent of the respondents, street vending is the main source of income. Likewise, for 89 percent of the respondents street vending is their full-time job. From this we can infer that vendors 
joined informality because of their exclusion from formal employment opportunities and institutions. Coming to experience, 57 percent of the respondents had previous business experiences. About 45 percent of the respondents sell their products in the commercial districts of the city.

Street businesses are very small-scale and ownership is dominated by a single person. The average number of workers is 1.25 persons per enterprise. On the average, vendors work for 10 hours a day. The average monthly profit is 764 ETB. The average age of business is 7 years. About 81 percent of the respondents did not have any vocational training. For 93 percent of the respondents, the sources of working capital are family, friends, and acquaintances. The average working capital is 1121 ETB.

\subsection{Estimation Results and Discussion}

Table 3 below provides the estimation results of the four regression models. The models significantly predict profit (see the $\mathrm{F}$ statics). The results of the IV estimators show a decline in the $\mathrm{R}^{2}$ and adjusted $\mathrm{R}^{2}$ from a value of 0.4850 (OLS) to 0.4335 in case of the three IV estimators where SC is instrumented for. This shows that when the endogenous effect of SC is circumvented, the $\mathrm{R}^{2}$ has declined. All the estimation results are consistent across the three IV estimators. Those variables which were significant in the OLS model are also significant in the case of IV estimators.

As shown in Table 3, some results match our expectations and some others failed to go with the expected sign and strength. On human capital side, contrary to our expectations, the results show that education, vocational training, and business experience are not statically significant. This is probably because for poor people who are characterised by limited skills and low education levels, street vending is the only way out that helps them to earn a living. Street vending is not discriminating people and every migrant to the city can join it without any educational or training background unlike the formal sector. Gender has the expected negative sign and is statically significant at 1 percent. The coefficient for gender indicates that average monthly profit is 29 percent lower for women than men. This might be attributed to many probable causes. To start with, women do have double responsibility in taking care of household duties and managing street businesses. Their day starts early in the morning with household work and then going to their street business. After working for some hours in streets, they have to go back home to do household chores. Due to this, women may devote less time in street vending. Most women are also working in permanent places and their businesses are located near their homes where they cannot get many customers. In addition, women start their business with low amount of capital than their male counterparts. Moreover, women are engaged in very small businesses which are extensions of their reproductive role including cooked and non-cooked food stuffs. These businesses demand low capital and generate lower income levels. 
Table 3: Results of enterprise profit under OLS and Instrumental variables estimation

\begin{tabular}{|c|c|c|c|c|}
\hline \multirow[b]{2}{*}{ Variables } & \multirow[b]{2}{*}{ OLS } & \multicolumn{3}{|c|}{ Instrumental Variables Estimation } \\
\hline & & $2 S L S$ & LIML & $G M M$ \\
\hline SC volume & $\begin{array}{c}0.00070^{* * *} \\
(4.48)\end{array}$ & $\begin{array}{l}0.00128^{* *} \\
(2.49)\end{array}$ & $\begin{array}{c}0.00128^{* *} \\
(2.49)\end{array}$ & $\begin{array}{c}0.00128^{* *} \\
(2.42)\end{array}$ \\
\hline Education & $\begin{array}{c}0.00231 \\
(0.36)\end{array}$ & $\begin{array}{c}0.00252 \\
(0.33)\end{array}$ & $\begin{array}{c}0.00252 \\
(0.33)\end{array}$ & $\begin{array}{c}0.00245 \\
(0.32)\end{array}$ \\
\hline Vocational training $(1=$ yes $)$ & $\begin{array}{c}0.01625 \\
(0.21)\end{array}$ & $\begin{array}{c}0.02767 \\
(0.36)\end{array}$ & $\begin{array}{c}0.02767 \\
(0.36)\end{array}$ & $\begin{array}{c}0.02785 \\
(0.37)\end{array}$ \\
\hline $\begin{array}{l}\text { Business } \\
\text { experience }(1=y e s)\end{array}$ & $\begin{array}{c}0.04789 \\
(0.00)\end{array}$ & $\begin{array}{c}0.04859 \\
(0.81)\end{array}$ & $\begin{array}{c}0.04859 \\
(0.81)\end{array}$ & $\begin{array}{c}0.04889 \\
(0.77)\end{array}$ \\
\hline Gender (women=1) & $\begin{array}{c}-0.30029^{* * *} \\
(-3.75)\end{array}$ & $\begin{array}{c}-0.29096^{* * *} \\
(-3.65)\end{array}$ & $\begin{array}{c}-0.29096^{* * *} \\
(-3.64)\end{array}$ & $\begin{array}{c}-0.29076^{* * *} \\
(-3.51)\end{array}$ \\
\hline Marital status (married $=1$ ) & $\begin{array}{c}0.56662^{* * *} \\
(3.13)\end{array}$ & $\begin{array}{c}0.87813^{* * *} \\
(2.75) \\
\end{array}$ & $\begin{array}{c}0.87816^{* * *} \\
(2.75) \\
\end{array}$ & $\begin{array}{c}0.87694^{* * *} \\
(2.81) \\
\end{array}$ \\
\hline Age of the respondent & $\begin{array}{c}0.00925^{*} \\
(1.68)\end{array}$ & $\begin{array}{c}0.00980^{*} \\
(1.78)\end{array}$ & $\begin{array}{c}0.00980^{*} \\
(1.78)\end{array}$ & $\begin{array}{c}0.00980^{*} \\
(1.70)\end{array}$ \\
\hline Working age family size & $\begin{array}{c}0.01674 \\
(0.86)\end{array}$ & $\begin{array}{c}0.00090 \\
(0.04)\end{array}$ & $\begin{array}{c}0.00090 \\
(0.04)\end{array}$ & $\begin{array}{c}0.00087 \\
(0.04)\end{array}$ \\
\hline Working capital & $\begin{array}{l}0.00006^{* * *} \\
(2.95)\end{array}$ & $\begin{array}{c}0.00006^{* * *} \\
(2.59)\end{array}$ & $\begin{array}{c}0.00006^{* * *} \\
(2.59)\end{array}$ & $\begin{array}{c}0.00006^{* * *} \\
(2.84)\end{array}$ \\
\hline $\begin{array}{l}\text { Business } \\
\text { location(1=centre) }\end{array}$ & $\begin{array}{c}0.06541 \\
(0.95)\end{array}$ & $\begin{array}{c}0.00779 \\
(0.09)\end{array}$ & $\begin{array}{c}0.00778 \\
(0.09)\end{array}$ & $\begin{array}{c}0.00870 \\
(0.10)\end{array}$ \\
\hline Ethnic Gurage & $\begin{array}{l}0.28152^{* * *} \\
(3.64)\end{array}$ & $\begin{array}{c}0.25027^{* * *} \\
(3.08)\end{array}$ & $\begin{array}{l}0.25027^{* * *} \\
(3.08)\end{array}$ & $\begin{array}{l}0.25068^{* * *} \\
(2.98)\end{array}$ \\
\hline Ethnic Amhara & $\begin{array}{c}0.11449 \\
(1.48)\end{array}$ & $\begin{array}{c}0.09849 \\
(1.27) \\
\end{array}$ & $\begin{array}{c}0.09849 \\
(1.27) \\
\end{array}$ & $\begin{array}{c}0.09867 \\
(1.27) \\
\end{array}$ \\
\hline Age of business & $\begin{array}{c}6.78006 \\
(0.00)\end{array}$ & $\begin{array}{c}0.00241 \\
(0.30)\end{array}$ & $\begin{array}{c}0.00241 \\
(0.30)\end{array}$ & $\begin{array}{c}0.00241 \\
(0.31)\end{array}$ \\
\hline Gender*marital status & $\begin{array}{c}-0.29734^{* *} \\
(-2.18)\end{array}$ & $\begin{array}{c}-0.30789^{* *} \\
(-2.27)\end{array}$ & $\begin{array}{c}-0.30789^{* *} \\
(-2.27)\end{array}$ & $\begin{array}{c}-0.30786^{* *} \\
(-2.41)\end{array}$ \\
\hline Marital status*sc volume & $\begin{array}{c}-0.00102^{* * *} \\
(-4.04)\end{array}$ & $\begin{array}{c}-0.00156^{* * *} \\
(-2.98)\end{array}$ & $\begin{array}{c}-0.00156^{* * *} \\
(-2.98)\end{array}$ & $\begin{array}{c}-0.00156^{* * *} \\
(-3.07)\end{array}$ \\
\hline Constant & $\begin{array}{l}5.79923^{* * *} \\
(29.90)\end{array}$ & $\begin{array}{c}5.61682^{* * *} \\
(22.77)\end{array}$ & $\begin{array}{c}5.61682^{* * *} \\
(22.77)\end{array}$ & $\begin{array}{l}5.61769^{* * *} \\
(23.92)\end{array}$ \\
\hline F statistic/Wald $\mathrm{Chi}^{2}$ & $8.66^{* * *}$ & $117.71^{* * *}$ & $117.71^{* * *}$ & $170.91^{* * *}$ \\
\hline $\mathrm{R}^{2}$ & 0.4850 & 0.4335 & 0.4335 & 0.4340 \\
\hline
\end{tabular}

Note: Figures in parenthesis are t values for OLS and $₹$ - values for IV estimators. ${ }^{* * *}$ Significant at $1 \%$, ${ }^{* *}$ significant at $5 \%$ and ${ }^{*}$ Significant at $10 \%$.

Ethnicity is presumed to be a factor that influences enterprise performance. As shown in Table 3, being ethnically Gurage is positively correlated with profit and the correlation is significant at 1percent level. Being Gurage increases profit by 25 percent compared with the Ormos. But being a member of the Ambara ethnic group does not have a significant effect on profit compared to the Oromos. This finding is consistent with other studies. For example, a study by Mengistae (2001) has shown that enterprises owned by the Gurage, despite their low educational level, perform better than members of other ethnic groups such as the Amharas who have relatively higher level of education. This is probably because the Gurages are known for their hard-work and business skills. The Gurages are also well-known for helping each-other and they do have high degree of kin and ethnic solidarity. The data collected through name generators also indicate that 
Gurages have the highest ethnic homophily index of -0.79 compared with the Oromos, -0.28 and the Ambaras, 0.04. In addition, 84 percent of the Gurages personal network is composed of kinship and friendship ties. This figure is 69 percent and 59 percent for the Oromos and the Ambaras, respectively.

The coefficient of marital status is positive and is statistically significant at 1 percent level. The positive relationship reflects that married vendors perform better than unmarried ones. The result indicates that being married increases profit by 88 percent compared to unmarried ones, cateris paribus. However, the coefficient of the interaction term between gender and marital status is negative and is significant at 5 percent level. This result implies that being married women reduces profit by 31 percent compared to unmarried men or unmarried women. This reflects that having a spouse makes women to be in an unfavourable position because usually they are not the sole decision makers of their businesses. According to the norm in the Ethiopian society, it is usually the husband who makes decisions in the household. Even when women are involved in some household discussions, the final decision is made by the husband.

The variable working capital has the expected sign and is significant at 1percent level. The coefficient shows that in each 1000 ETB increase in start-up capital, average monthly profit increases by 6 percent, cateris paribus. The coefficient of age of a respondent is positive and is statistically significant at 10 percent level. The result shows that for each one year increase in age, we expect to see about a 0.92 percent increase in enterprise income, cateris paribus. The contribution of working age family size appears to be insignificant in enterprise performance. One likely explanation is that owing to the small-scale of operation, street businesses are managed by the owner and hence family members are not involved in microenterprises activities. Among business characteristics, place of vending has no significant effect on profit. This is perhaps because most of the street vendors are mobile in that they swap among different sites of the city taking advantage of different types of customers and following different patterns of urban movement.

Getting back to our main variable of interest, i.e., SC, we observe that SC volume has got the expected sign and is statically significant at 5 percent level. A street vendor earns better profit than anyone else the higher the level of SC volume he/she accesses. The coefficient shows that a10 percent increase in SC volume raises profit by 1.2 percent, ceteris paribus. This reveals that SC contributes significantly to enterprise performance than human capital variables do. Previous studies corroborate our finding. For instance, Fafchamps and Minten (2002) found that SNs have a significant positive impact on entrepreneurs' economic performance. They also found that while SC was strong and robust in predicting the performance of agricultural traders, human capital variables such as years of schooling and years of experience were found to be less robust in predicting performance. Grootaert (1999) also founds that for the poor segments of the society returns of SC are higher than returns of human capital. For the rich, however, the returns of human capital are higher than the returns of SC. Likewise, Grootaert, Oh, and Swamy (2002) found out that poor households and those who own small tract of land get higher returns from SC than rich ones.

When treated in parallel, the variables marital status and SC volume have positive and significant effect on profit. But when marital status interacts with SC volume, the coefficient becomes negative and is statistically significant at 1 percent level. The result indicates that married vendors benefit less from SC than unmarried vendors 
do. Each 100 unit of SC volume is worth about 17 percent less for a married vendor than it is for unmarried vendors. This is probably because in our sample the majority of married vendors are women. Being married women implies that they do have many household responsibilities and thus they might not get enough time to interact with people and accumulate large volumes of SC. Even when they do have time to interact with people, they are usually under the surveillance of their husbands. Women entrepreneurs are, thus, struggle to develop appropriate and effective networks due to their role as home-takers (Klyver and Grant, 2010). This in one way or another cripples the significance of network resources to married women vendors.

\section{Conclusion}

This paper examined the potential contribution of SC to the informal economy. Specifically, we investigated how access to network resources influence enterprise profit. To do so, we collect data using position generator surveys. Data were analysed using OLS and IV estimators. SC volume was an explanatory variable and other variables such as human capital, financial capital, and enterprise and entrepreneur characteristics were controlled for in the analysis. After using IV estimators to control for possible endogeneity of SC volume, the results revealed that SC is a statistically significant predictor of street vendors' profit. Human capital variables such as education, vocational training, and previous business experience are not significant to predict street vendors' income. This shows that $\mathrm{SC}$ is by far the most important resource that helps the poor street vendors to perform better than human capital variables do. In sum, our empirical results of the relationship between SC and street vendors' profit have confirmed the validity of our hypothesis and tend to corroborate Lin's propositions in the contexts of the informal economy of Ethiopia.

\section{References}

Adam, F., \& Rončević, B. (2003). Social Capital: Recent Debates and Research Trends. Social Science Information, 42(2), 155-183.

Aldrich, H. E., \& Zimmer, C. (1986). Entrepreneurship through Social Networks (SSRN Scholarly Paper No. ID 1497761). Rochester, NY: Social Science Research Network.

Batjargal, B. (2003). Social Capital and Entrepreneurial Performance in Russia: A Longitudinal Study. Organization Studies, 24(4), 535-556.

Baum, C. F. (2006). An Introduction to Modern Econometrics Using Stata. Stata Press.

Baum, J. A. C., Calabrese, T., \& Silverman, B. S. (2000). Don't go it alone: Alliance network composition and start-ups' performance in Canadian biotechnology. Strategic Management Journal, 21(3), 267-294.

Becker, K. F., \& Sida. (2004). the Informal Economy: Fact Finding Study. Sida.

Berrou, J. P., \& Combarnous, F. (2012). The Personal Networks of Entrepreneurs in an Informal African Urban Economy: Does the "Strength of Ties" Matter? Review of Social Economy, 70(1), 1-30.

Berrou, J.P., \& Combarnous, F. (2011). Testing Lin's Social Capital Theory in an Informal African Urban Economy. Journal of Development Studies, 47(8), 1216-1240.

Bian, Y., and Ang, S. (1997). Guanxi Networks and Job Mobility in China and Singapore. Social Forces, 75(3), 981-1005.

Bigsten, A. (2007). The small, the young, and the productive: determinants of manufacturing firm growth in Ethiopia.

Birley, S. (1985). The role of networks in the entrepreneurial process. Journal of Business Venturing, 1(1), 107117.

Boxman, E. A. W., De Graaf, P. M., \& Flap, H. D. (1991). The impact of social and human capital on the income attainment of Dutch managers. Social Networks, 13(1), 51-73. 
Brüderl, J., \& Preisendörfer, P. (1998). Network support and the success of newly founded business. Small Business Economics, 10(3), 213-225.

Campbell, K. E., Marsden, P. V., \& Hurlbert, J. S. (1986). Social resources and socioeconomic status. Social Networks, 8(1), 97-117.

Cantner, U., Conti, E., and Meder, A. (2009). Networks and innovation: the role of social assets in explaining firms' innovative capacity. Jena economic research papers.

Carrasco, J. A., B. Hogan, B. Wellman, and E. J. Miller. 2008. "Collecting Social Network Data to Study Social Activity-travel Behavior: An Egocentric Approach.” Environment and Planning. B, Planning \& Design 35 (6): 961.

Coleman, J. S. (1988). Social capital in the creation of human capital. American Journal of Sociology, 95-120.

CSA. (2008). Summary and Statistical Report of the 2007 Population and Housing Census. Federal Democratic Republic of Ethiopia Population Census Commission

Edwards, G. (2010). Mixed-method approaches to social network analysis (Working Paper). NCRM.

Fafchamps, M., \& Minten, B. (1999). Relationships and traders in Madagascar. The Journal of Development Studies, 35(6), 1-35.

Fafchamps, M., \& Minten, B. (2001). Social capital and agricultural trade. American Journal of Agricultural Economics, 83(3), 680-685.

Fafchamps, M., \& Minten, B. (2002). Returns to social network capital among traders. Oxford Economic Papers, 54(2), 173-206.

Gambetta, D. (1996). The Sicilian Mafia: The Business of Private Protection. Harvard University Press.

Ganzeboom, H. B. G., \& Treiman, D. J. (2003). Three Internationally Standardised Measures for Comparative Research on Occupational Status. In J. H. P. Hoffmeyer-Zlotnik \& C. Wolf (Eds.), Advances in Cross-National Comparison (pp. 159-193). Springer US.

Garoma, B. F. (2012, November 5). Determinants of Microenterprise Success in the Urban Informal Sector of Addis Ababa: A Multidimensional Analysis. International Institute of Social Studies of Erasmus University.

Glaeser, E. L., Laibson, D., \& Sacerdote, B. (2002). An economic approach to social capital. The Economic Journal, 112(483), F437-F458.

Granovetter, M. S. (1973). The strength of weak ties. American Journal of Sociology, 1360-1380.

Grootaert, C., \& Bastelaer, T. van. (2002). The Role of Social Capital in Development: An Empirical Assessment. Cambridge University Press.

Grootaert, C., Oh, G.-T., \& Swamy, A. (2002). Social Capital, Household Welfare and Poverty in Burkina Faso. Journal of African Economies, 11(1), 4-38.

Honig, B. (1998). What determines success? examining the human, financial, and social capital of Jamaican micro entrepreneurs. Journal of Business Venturing, 13(5), 371-394.

Hopkins, N. (2011). Religion and Social Capital: Identity Matters. Journal of Community \& Applied Social Psychology, 21(6), 528-540.

Kantor, P. (2005). Determinants of Women's Microenterprise Success in Ahmedabad, India: Empowerment and Economics. Feminist Economics, 11(3), 63-83.

Klyver, K., \& Grant, S. (2010). Gender differences in entrepreneurial networking and participation. International Journal of Gender and Entrepreneurship, 2(3), 213-227.

ILO.(1972. Employment, Incomes, and Equality: A Strategy for Increasing Productive Employment in Kenya. Geneva: International Labor Office.

Lai, G., Lin, N., \& Leung, S.-Y. (1998). Network resources, contact resources, and status attainment. Social Networks, 20(2), 159-178.

Larson, A. (1992). Network Dyads in Entrepreneurial Settings: A Study of the Governance of Exchange Relationships. Administrative Science Quarterly, 37(1), 76-104.

Light, I. H., \& Isralowitz, R. (1997). Immigrant entrepreneurs and immigrant absorption in the United States and Israel. Ashgate.

Lin, N. (1999a). Building a network theory of social capital. Connections, 22(1), 28-51.

Lin, N. (1999b). Social networks and status attainment. Annual Review of Sociology, 467-487.

Lin, N. (2002). Social Capital: A Theory of Social Structure and Action. Cambridge University Press.

Lin, N., \& Dumin, M. (1986). Access to occupations through social ties. Social Networks, 8(4), 365-385.

Lin, N., Fu, Y., \& Hsung, R.-M. (2001). The position generator: Measurement techniques for investigations of social capital. Social Capital: Theory and Research. New York: Aldine de Gruyter, 57-81.

Lourencco-Lindell, I. (2002). Walking the tight rope: Informal livelihoods and social networks in a West African city. Stockholm. Retrieved from http://su.diva-portal.org/smash/record.jsf?pid=diva2:189997 
McPherson, M. A. (1995). The hazards of small firms in Southern Africa. Journal of Development Studies, 32(1), $31-54$.

McPherson, M. A. (1996). Growth of micro and small enterprises in southern Africa. Journal of Development Economics, 48(2), 253-277.

Meagher, K. (2005). Social capital or analytical liability? Social networks and African informal economies. Global Networks, 5(3), 217-238.

Mengistae, T. (2001). Indigenous ethnicity and entrepreneurial success in Africa: some evidence from Ethiopia (Vol. 2534). World Bank, Development Research Group, Macroeconomics and Growth.

Miguel, E. (2004). Tribe or Nation? Nation Building and Public Goods in Kenya versus Tanzania. World Politics, 56(03), 328-362.

Muhib, F. B., Lin, L. S., Stueve, A., Miller, R. L., Ford, W. L., Johnson, W. D., \& Smith, P. J. (2001). A venue-based method for sampling hard-to-reach populations. Public Health Reports, 116(Suppl 1), 216-222.

Narayan, D., \& Pritchett, L. (1999). Cents and Sociability: Household Income and Social Capital in Rural Tanzania. Economic Development and Cultural Change, 47(4), 871-897.

Odella, F. (2006). "Using Ego-network in Surveys: Methodological and Empirical Research Issues." In International Conference on Network Science, Bloomington, Indiana.

Podolny, J. M., \& Page, K. L. (1998). Network Forms of Organization. Annual Review of Sociology, 24(1), 57-76

Portes, A. (1998a). Social Capital: Its Origins and Applications in Modern Sociology. Annual Review of Sociology, 24, 1-24.

Portes, A. (1998b). The Economic Sociology of Immigration: Essays on Networks, Ethnicity, and Entrepreneurship. Russell Sage Foundation.

Robb, A. M., \& Fairlie, R. W. (2007). Determinants of business success: an examination of Asian-owned businesses in the United States (No. 2566). IZA Discussion Papers.

Rooks, G., Szirmai, A., \& Sserwanga, A. (2009). The interplay of buman and social capital in entrepreneurship in developing countries: The case of Uganda (No. 2009.09). Research paper UNU-WIDER. Retrieved from http://www.econstor.eu/handle/10419/45159

Rutashobya, L. K., Allan, I. S., \& Nilsson, K. (2009). Gender, social networks, and entrepreneurial outcomes in Tanzania. Journal of African Business, 10(1), 67-83.

Salganik, M. J., \& Heckathorn, D. D. (2004). Sampling and Estimation in Hidden Populations Using Respondent-Driven Sampling. Sociological Methodology, 34(1), 193-240.

Singh, K. (2007). Quantitative Social Research Methods. SAGE.

Singh, R. P., Hills, G. E., Lumpkin, G. T., \& Hybels, R. C. (1999). The entrepreneurial opportunity recognition process: examining the role of self-perceived alertness and social networks. In Academy of Management Meeting, Chicago, IL.

Son, J., \& Lin, N. (2012). Network diversity, contact diversity, and status attainment. Social Networks, 34(4), 601-613.

Thrikawala, S. S. (n.d.). The Role of Networking for the Success of SMEs in Sri Lanka. Retrieved from http://www.wbiconpro.com/476-Sujani.pdf

UN-Habitat. (2008). Ethiopia: Addis Ababa Urban Profile. United Nations Human Settlements Program, UNON, Publishing Services Section, Nairobi, Kenya.

Uzzi, B. (1996). The Sources and Consequences of Embeddedness for the Economic Performance of Organizations: The Network Effect. American Sociological Review, 61(4), 674-698.

Uzzi, B. (1997). Social Structure and Competition in Interfirm Networks: The Paradox of Embeddedness. Administrative Science Quarterly, 42(1), 35-67.

Uzzi, B. (1999). Embeddedness in the Making of Financial Capital: How Social Relations and Networks Benefit Firms Seeking Financing. American Sociological Review, 64(4), 481-505.

Van der Gaag, M. V. D., Snijders, T. A. B., \& Flap, H. D. (2004). Position Generator measures and their relationship to other Social Capital measures *.

Van der Gaag, M. P. J. van der. (2005). Measurement of Individual Social Capital. F\&N Boekservices.

Van Der Gaag, M., \& Snijders, T. A. B. (2005). The Resource Generator: social capital quantification with concrete items. Social Networks, 27(1), 1-29.

Wooldridge, J. M. (2010). Econometric Analysis of Cross Section and Panel Data. MIT Press.

Zaheer, A., \& McEvily, B. (1999). Bridging ties: A source of firm heterogeneity in competitive capabilities. Strategic Management Journal, 20(12), 1133. 